\title{
Marketing Constraints among Smallholder Farmers in South Africa: An Overview of Potato Market Outlets in Lusikisiki Township.
}

\author{
Nwafor, Christopher Ugochukwu \\ manchrizzo@hotmail.com \\ Central University of Technology (CUT), South Africa.
}

\begin{abstract}
Recent studies of the difficulties faced by smallholder farmers in many developing countries have echoed their disconnection with formal markets. These limitations have been attributed to a number of factors including stringent quality and volume requirements, among others. While smallholder farmers seek access to formal markets, the existing alternatives through which they sell their produce remain obscure. Using an interview of market outlets and selected smallholder farmers in the area, the study applied a crop marketing index to examine the outlets currently used by farmers and the volume of potatoes sold in each. Findings indicate that smallholder farmers on average sold sixty-eight percent of their produce. The outlet mostly used by farmers was street vendors because the large supermarkets sold potatoes supplied from external sources. It would be helpful for smallholder farmers to aggregate their produce through producer and marketing cooperatives, to better engage with these formal market outlets.
\end{abstract}

Keywords: cooperatives, crop marketing index, municipality, smallholder-farmer, supermarkets, vendors

\section{Introduction}

Markets play an important role in the growth of all categories of producers, and the limited access to agricultural markets among smallholder farmers especially in the rural areas represent a key challenge. Salami et al. (2010) viewed improved access to markets for both inputs and produce, as a major requirement for the transformation of the smallholder sector from subsistence to commercial production. Without access to cost-effective markets especially for their produce, Ngemntu (2010) pointed out that smallholders are denied the beneficial effects from agriculture and growth. The precarious situation facing subsistent and smallholder farmers in Africa have been reported by Begashaw et al. (2019), wherein they surmised that current demographic and environmental pressures portend negative consequences for the growth of this group of farmers.

Markets are vital to smallholder farmers and range from informal small village-level markets to large regional outlets. It is the key for smallholder farmers to earn from the sale of their produce, offering the possibility of an income and making profits which is a strong incentive 
that encourage farmers to stay in production and grow. The limited ability among many smallholder farmers to access viable markets for their output is considered a major challenge in the agriculture and rural development literature (NAMC, 2016). Many studies share a common ground related to marketing constraints faced by smallholder farmers, especially in many under-developed and developing countries (Khapayi and Celliers, 2016). The case of smallholder farmers in South Africa is worth exploring, due to the acclaimed disparity within the agricultural sector (Nwafor, 2015) as well as the perception regarding the inflexibility of the economy to engage and reward previously marginalized emerging farmers (Chikazunga and Paradza, 2012). This has discouraged many smallholder farmers from accessing formal markets, leading to their engagement with alternative informal channels for marketing (Nwafor, 2020).

This problem is however recognized as prevalent in many countries among emerging farmers and considered a constraint to the development of smallholder farmers (Bie'nabe and Vermuelen, 2011). Informal markets are therefore considered the most accessible markets for smallholder farmers, especially in developing countries such as South Africa where they utilize available informal markets to sell their produce (Baipheti and Jacobs, 2009; Ferris et al., 2014). Informal markets involve exchanges at the farm gate, roadside, village and rural markets, and may include some sales in the nearest urban centers. Accordingly, the informal markets are crucial to smallholder producers, and in some instances may provide short-term gains (Seville et al., 2011).

It is agreed however, that linking smallholders to formal markets remain a critical part of any long-term development or poverty reduction strategy (Ha et al., 2015). These markets are characterized by modern value-chain systems, and can link the more market-oriented smallholders with large commercial buyers. Formal markets offer remarkable prospects for growth to small scale producers, as they provide connections to reliable income streams and prospects of accessing additional support services. However, the often stringent quality standards, volume requirements as well as pricing lower than informal markets, are some of the many challenges which the farmers may have to contend with.

According to the Southern African Food Laboratory (2016), access to markets among smallholder farmers in South Africa is poorly understood. Despite many studies that have reported the constraints faced by smallholder farmers in accessing formal markets, there is little understanding of existing markets used and its relationship to farmers. This study hence 
focused on exploring the existing marketing sources among smallholder farmers within the potato distribution-chain in the selected area. Lusikisiki was selected as it is a rural town located in the district where many farmers are smallholders, and the major source of livelihoods is small-scale agriculture.

\section{Research questions}

1. From which source(s) are potatoes supplied to existing market outlets in the study area?

2. What quantities do smallholder potato farmers in the area market using existing outlets?

\section{Methodology}

\section{Study area}

Lusikisiki is a rural town within the Inquza Hills local municipality of the Eastern Cape Province. Other rural towns close to Lusikisiki are Flagstaff and Port St Johns which all form part of the Oliver Tambo District municipality. The town lies between the coordinates 31.368S and 29.576E and receives large amounts of rainfall ranging between 874-1060 millimeters per annum, especially during the summer months. Its average winter temperatures reach 8 degrees Celsius by night-time, and the area is habited mainly by Xhosa speaking members of the amaMpondo tribe. Subsistent agriculture is the major activity within the area, with smallholdings of mixed crop and livestock farming, few government services are available and administrative services are obtained in Flagstaff which is the administrative headquarters of the local municipality.

\section{Sampling}

The study involved 25 outlets selling potatoes within the study area, including small Spaza shops, fresh produce grocers, street vendors and supermarkets. Additionally 35 farmers growing potatoes within the area were interviewed on quantity of potatoes harvested and sold within the period.

\section{Data collection and Analysis}

Data collection was enabled by a schedule used to collect information from the outlets selling potatoes, and to interview participating farmers. The outlets were purposively selected and 
included all major outlets within the business zone, as well as street vendors identified through a non-random sampling approach. The collected information was entered into a database and analyzed using frequencies and percentages. The proportion of the farmer's crop marketed was calculated using a crop marketing or sales index. The index provides information about the farmers' marketing performance in relation to a specific crop (Rios et al., 2008), sometimes referred to as crop marketability index (CMI) in some studies (Osmani and Hossain, 2016), and is computed as the value of sales relative to the total value of output. This value will be zero for non-sellers, and more than zero for all sellers, with the highest index of one (1), where the farmer sells all of their produce.

\section{Results}

The potato market outlets in Lusikisiki area which were interviewed is shown in Table 1, and consists of different types of outlets, both formal and informal.

Table 1: Potato sales outlets interviewed.

\begin{tabular}{|c|c|c|}
\hline Outlet type & Number & Percent \\
\hline Supermarket & 7 & 28 \\
Local Grocer Shop & 3 & 12 \\
Informal Wholesaler & 2 & 8 \\
Street vendors & 13 & 52 \\
Total & 25 & 100 \\
\hline
\end{tabular}

Source: Survey data, 2019.

A total of twenty five outlets selling potatoes were interviewed to obtain information related to source of potato sold in the study area. The data shows that $28 \%$ of the outlets were supermarkets chains, grocer shops made up $12 \%$ of interviewed outlets, $8 \%$ were informal wholesalers (selling in bags) and street vendors (selling small retail volumes) made up the majority of respondents $(52 \%)$.

The data collected also shows the sources from which the outlets received their supplies of potato. The analysis in Figure 1 suggests that among the supermarkets, their stock mostly came from their external suppliers who were also supplying other branches, as a result of 
centralized procurement. Five of the supermarket chains received supplies from their centralized purchasing system, one supermarket received their potato supplies from commercial farmers with large farms located outside the study area, and one other supermarket received from a mix of centralized supplier, commercial and local smallholder farmers.

One of the informal wholesaler received supplies from commercial farms outside Lusikisiki and the other wholesaler got supplies from an external commodity supplier. Among the street vendors interviewed, six of them got their potato supplies from local smallholder farmers, four were supplied from commercial farms, two vendors received their supplies from external commodity suppliers, while one vendor purchased stock of potato from a local wholesaler.

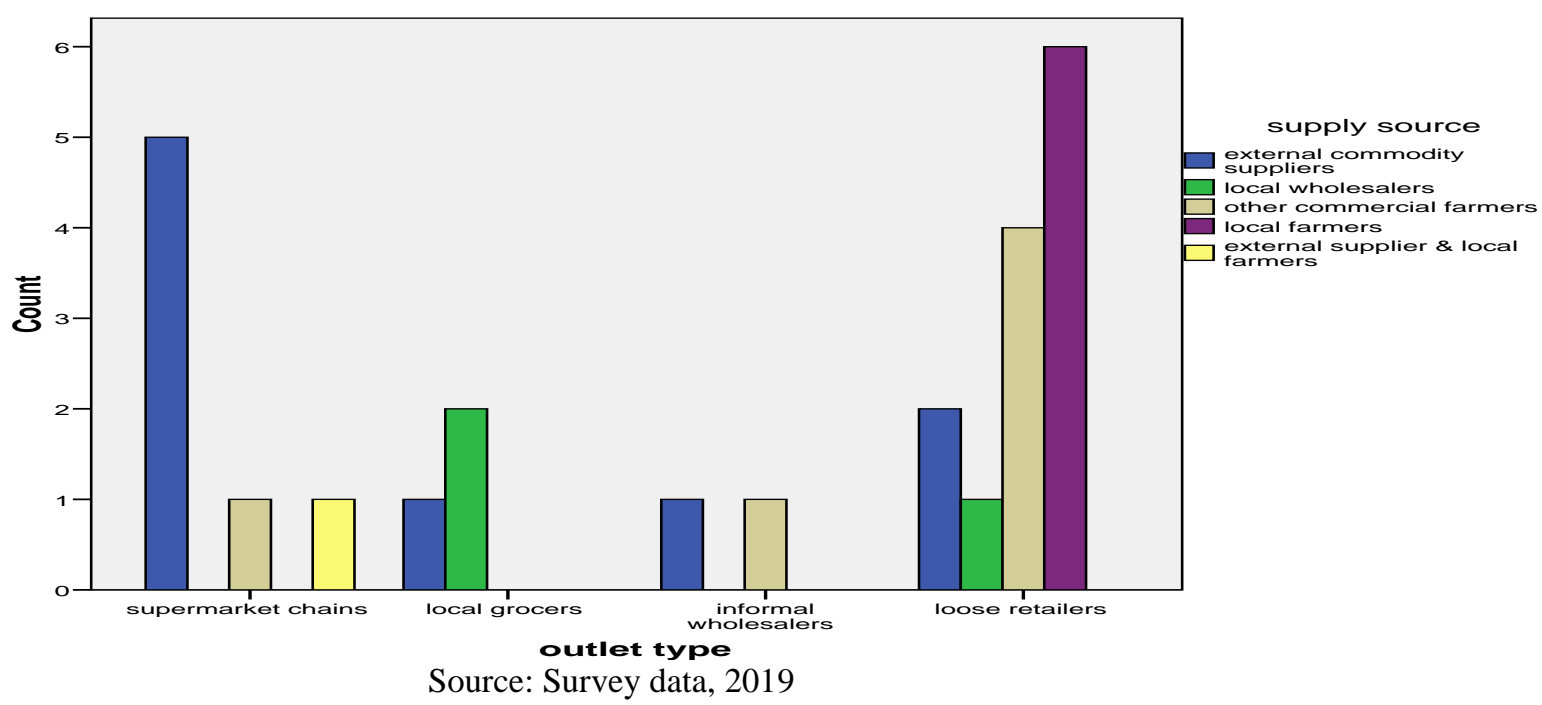

Figure 1: Supply source of potato sold in Lusikisiki Town.

A majority of the large outlets, five out of seven, were exclusively sourcing their potato supplies from external commodity suppliers. These consisted largely of supermarket chains in the study area that had a centralized supply source, and depended on supplies from their centralized purchasing system made up of external commodity agents or large scale potato producers. All the outlets interviewed obtained supplies from commercial farmers based outside the study area, and some except the supermarket chains, also obtained supplies from local informal wholesalers.

Apart from one of the supermarket stores, street vendors or informal 'loose retailers', who could be found in many spots around the business district, were the outlets selling potatoes 
supplied by local smallholder potato producers. Most of the outlets did not stock potatoes supplied by local farmers, and out of the 25 outlets interviewed only 6 sold potatoes supplied by local small scale farmers in the study area.

\section{Effort made by smallholder farmers to gain access to market outlets in the area}

The survey also requested information from the market outlets where potatoes are sold, for efforts made by local smallholder farmers to supply their produce. Many smallholder farmers in their effort to market their harvest, seek out opportunities available in the area by contacting the owners or store managers in the supermarkets and grocer shops as well as local merchants who act as middlemen, buying from farmers in the area and supplying to market outlets or selling in large quantities. Responses received from the outlets are shown in Table 2, outlining which outlets had been approached by local smallholder farmers as well as those selling potatoes supplied by the smallholder farmers within the area.

Table 2: Outlets approached and selling potatoes from local farmers

\begin{tabular}{|c|c|c|c|c|}
\hline \multirow[t]{2}{*}{ Outlet Type } & \multicolumn{2}{|c|}{ Approached by local farmers } & \multicolumn{2}{|c|}{ Selling potatoes from local farmers } \\
\hline & Yes & No & Yes & No \\
\hline Supermarket chain & $24 \%$ & $4 \%$ & $8 \%$ & $20 \%$ \\
\hline Local grocer shops & $4 \%$ & $8 \%$ & $0 \%$ & $12 \%$ \\
\hline Informal wholesalers & $8 \%$ & $0 \%$ & $0 \%$ & $8 \%$ \\
\hline $\begin{array}{l}\text { Street vendors } \\
\text { (retailers) }\end{array}$ & $48 \%$ & $4 \%$ & $16 \%$ & $36 \%$ \\
\hline (Total) & (84\%) & $(16 \%)$ & $(24 \%)$ & $(76 \%)$ \\
\hline
\end{tabular}

Source: Survey data, 2019

From Table 2 above, $84 \%$ of interviewed potato selling outlets had been approached by local farmers, seeking to supply potatoes. Only $16 \%$ of the respondents had not been approached by local smallholder farmers, and about $24 \%$ of the outlets were selling potatoes supplied by local smallholder producers. Clearly, the local smallholder farmers have made attempts to source large market outlets for their produce, with limited success. However, while some 
outlets interviewed claimed there were no obstacles to getting supplies from small scale farmers in the area, a number of obstacles constraining smallholder producers from supplying potato produce relate to centralized purchasing systems in place with large chain-stores such as Pick'n Pay, Super Spar, Boxers, Browns, Rhino Cash'n Carry and Checkout. Also, another identified issue was the ability of individual farmers to supply the volumes required.

The supply negotiation process, supplier registration requirements and on-boarding processes including payment systems of the large chain stores was also identified as bottlenecks for small scale producers. In some cases, local smallholders were blamed for their lack of followup on some opportunities; by not providing any feedback after being interviewed by headbuyers from the large chain supermarkets.

\section{Estimates of potato quantities marketed by existing outlets in the area}

Seventy six percent of the total quantities of potato sold in the area were dispensed by large outlets especially the supermarkets and informal wholesalers. Data from the survey shown in Table 3 indicates that each supermarket sold in excess of 250 bags of potatoes weekly; informal wholesalers sold more than 100 bags per week, while some local grocers sold less than 100 bags per week. Most of the informal vendors sold less than 20 bags of potatoes per week.

Table 3: Estimated quantities of potato sold weekly by individual outlets

\begin{tabular}{|c|c|c|}
\hline Quantity Sold (50kg Bags per week) & Outlet Type & Percent \\
\hline $250-600$ & Supermarket chain store & 40 \\
\hline $100-250$ & Informal wholesalers & 36 \\
\hline$>20<100$ & Local grocers & 20 \\
\hline
\end{tabular}

Source: Survey data, 2019 
The survey indicates that the informal vendors or retailers control a small slice of the market, based on the quantities sold per week. These informal vendors however, were the major outlets for smallholder potato farmers within the study area.

\section{Marketing of produce among the smallholder farmers}

From the smallholder farmers interviewed, the quantities of potatoes harvested and sold during the season were obtained. This information was used to calculate the proportion of produce marketed by the smallholder farmers in the area. The analysis of the data is provided in Table 4.

Table 4. Potato crop marketing index among smallholder farmers

\begin{tabular}{|c|c|c|c|c|c|}
\hline Variable & Obs. & Mean & Std. Dev. & Min. & Max. \\
\hline Potato produced (kg) & 35 & 125 & 72 & 88 & 235 \\
\hline Potato sold (kg) & 35 & 85 & 31 & 45 & 194 \\
\hline Crop Marketing Index & 35 & 0.68 & 0.12 & 0.51 & 0.82 \\
\hline
\end{tabular}

Source: Calculations from data collection 2019

Results from the study indicate that most of the farmers sold their potato crop during the period, through existing market outlets. At a calculated marketing index of 0.68 , this indicates that on average sixty-eight percent of the potato crop produced by the farmers in the area was sold. All the farmers sold, at least, more than half of their produce (51\%) while for others the quantity of produce sold was as high as eighty-two percent (82\%), denoted by the minimum and maximum values of the crop marketing index (CMI). The finding is aligned to the SAFL (2016) report that the average smallholder farmer markets 50 to 75 per cent of what they produce, by sending a larger portion to the informal market comprising bakkie (small truck) traders, hawkers and members of the local community. Formal markets that engaged with smallholder farmers did so because of the quality of their produce, potentially as a result of shorter transport distances, and because of the flexibility of the marketing relationships with smallholder farmers. It is worth noting that, not all the potato crop harvested was sold among these smallholder farmers- though an important indicator for household food security, which might also point to their inability to market all of the produce, and confirms the difficulties faced by smallholder farmers in marketing their produce. 


\section{Discussion}

There is a large market for potatoes which the small scale farmers need to explore, through either increasing the quantities supplied to informal vendors, or trying to secure supply agreements with the larger outlets such as the formal supermarket-chains or the informal wholesalers. The result obtained agrees with Ngemntu (2010), who indicated that the majority of smallholder farmers faced serious competition in marketing their produce. The smallholder farmers had hitches accessing formal supply chains, which confirm the view of Schalkwyk et al. (2012) and others, who outlined a number of factors that challenged farmers in accessing formal markets.

The survey shows that most of the large chain-stores in the survey area had centralized purchasing systems, and even some suppliers were wary of smallholder farmers' who did not follow-up on their supply-related queries. This is in line with the earlier findings of Barlow and van Dijk (2013) from their market investigation, which reported that most large retailers had moved away from direct deliveries by suppliers, to a supply mechanism operated from larger regional distribution centers. They also reported on the lack of commitment from smallholder farmers, who are accused of disregarding supply agreements in their quest for short-term gains.

All in all, the difficulties faced by smallholders in supplying produce to large chain-stores are not unexpected. Heijden and Vink (2013) in their critical review of marketing approaches, outlined that a close examination of the chain-stores model suggests an inherently hostile orientation towards smallholder producers, related to the challenges in obtaining access to such markets. In supporting this view, the SAFL (2016) report admitted that few smallholder farmers had access to the procurement system of large national retailers.

The access by smallholder farmers to formal markets has been the subject of numerous studies and commentary. Though a majority view are optimistic about the prospects for increasing smallholder farmer incomes (World Bank, 2008), an alternative viewpoint sketches the difficult barriers that impede smallholders from entry and benefitting from these markets. These barriers may however be overcome with increased government support to the smallholder sector. This standpoint is informed by the view among a majority of the respondents who did not see any obstacles to smallholders' supply of produce. Some of these outlets are franchises or owner run stores, able to purchase outside the centralized buying structure, therefore procuring directly from farmers or suppliers, and hence providing an 
avenue for smallholder farmers to access formal chain stores. Also there are issues of delivery frustrations among some of the outlets due to the late arrival of requested supplies from their centralized purchasing system (Personal Communication, 2018). This also indicates that the central purchasing system is sometimes affected by complex logistical problems, and might offer an opening for smallholders.

Another window of opportunity for smallholders to access formal markets (such as chainstores) is the government procurement policy. The Broad Based Black Economic Empowerment (BBBEE) policy requires large national retailers to purchase a certain percentage of produce from smallholder farmers, and Barlow \& van Dijk (2013) report that various initiatives have been adopted by the chain-stores, for implementing processes through which smallholders receive sufficient support to access their supply chains.

\section{Conclusion}

The study examined market constrains faced by smallholder farmers through an overview of the potato market in the Lusikisiki Town. Using an interview approach to collect information from existing market outlets selling potatoes in the area, the findings show that the large supermarkets relied mainly on a centralized purchasing system that supplied potatoes from external agents. The large informal wholesalers purchased their potato stock from commercial farmers outside the study area, while fresh grocer shops and street vendors utilized a mix of external agents and local smallholder farmer sources for their potato. Though most of these existing market outlets had been approached by smallholder farmers seeking a supply arrangement for their produce, very few of the large supermarkets sold potatoes supplied by local smallholder farmers.

Many of the smallholder farmers sold their produce through informal outlets such as street vendors, and the study found that on average smallholder farmers in the area marketed sixtyeight percent of their production, with a minimum market index of 0.51 and maximum market index of 0.82 for the potato crop.

Based on the foregoing, the study recommends strengthening of the farmer associations in the area. This is to take advantage of better organizing and increased bargaining power of cooperatives, and assist farmers with planning of their crop cycles, improved agronomic practices, aggregation of quantities, grading and packaging. It is anticipated this will enable positive engagement with large buyers or the centralized purchasing systems of supermarkets. 


\section{Reference}

Baipheti, M. and Jacobs, P. 2009. The contribution of subsistence farming to food security in South Africa. Agrekon, Vol. 48(4): 459-482.

Barlow, L. and van Dijk, N. 2013. Market Investigation of Black Emerging Farmers in South African Horticulture. Study Report. BoP Innovation Centre \& ICCO Cooperation.

Begashaw, B., Verburg, G., Yamauchi, F., Fattibene, B. and Yasuo, F. 2019. Linking Smallholder Production with Value-added Food Markets. Available at https://t20japan.org/wpcontent/uploads/2019/03.pdf (Accessed on 14/02/2020).

Bienabe, E. and Vermeulen, H. 2011. Improving smallholders' market participation: Insights from a business scheme for maize in Limpopo Province, South Africa. Development Southern Africa, 25(4), 493-507.

Chikazunga, D. and Paradza, G. 2012. Can smallholder farmers find a home in South Africa's foodsystem? Lessons from Limpopo Province. The Institute for Poverty, Land and Agriculture Studies (PLAAS).

Ferris, S., Robbins, P., Best, R., Seville, D., Buxton, A., Shriver, J. and Wei, E. 2014. Linking Smallholder Farmers to Markets and the Implications for Extension and Advisory Services. MEAS Discussion Paper 4. May 2014. Available at: www.meas-extension.org (Accessed on 10/10/2019).

Ha, T. M., Bosch, O. J. and Nguyen, N. C. 2015. Systemic interventions addressing market access challenges of smallholder vegetable farmers in Northern Vietnam. International Journal of Markets and Business Systems, 1(2):136-158.

Heijden, T. and Vink, N. 2013. Good for Whom? Supermarkets and Small Farmers in South Africa. A critical review of current approaches to increasing access to modern markets. Agrekon, 52(1): 6886.

Khapayi, M. and Celliers, P.R. 2016. Factors limiting and preventing emerging farmers to progress to commercial agricultural farming in the King William's Town area of the Eastern Cape Province, South Africa. South African Journal of Agricultural Extension Vol. 44 (1). http://dx.doi.org/10.17159/2413-3221/2016/v44n1a374.

NAMC- National Agriculture Marketing Council, 2016. Measuring and Tracking Smallholder Market Access in South Africa. Working Paper Series, No. 2016-03. Available at www.namc.co.za/researchportal/ (Accessed on 10/10/2019). 
Ngemntu, S. 2010. An investigation of the production and marketing challenges faced by smallholder farmers in Amahlathi Municipality: A case study of Zanyokwe Irrigation Scheme and Silvindlala Women's Project. Thesis, Faculty of Science and Agriculture. University of Fort Hare, Alice.

Nwafor, C.U. 2015. Prospects for Commercialization among Small-scale Potato Farmers in Bizana. Unpublished Thesis. Central University of Technology, Free State. South Africa. Available online http://ir.cut.ac.za/bitstream/handle/11462/1168/Nwafor\%2C\%20Christopher\%20Ugochukwu.pdf.

Nwafor, C.U. 2020. The Market Channel Preference among Smallholder Farmers in South Africa: A Food Security Perspective. Available online https://www.preprints.org/manuscript/202003.0062/v1 (Accessed on 09/03/2020).

Osmani, A.G. and Hossain, E. 2016. Smallholder Farmers' Market Orientation and the Factors Affecting it in Bangladesh. Economic Insights- Trends and Challenges, Vol. 5(30): 9-18.

Rios, A.R., Masters, A.W. and Shively, G.E. 2008. Linkages between market participation and productivity: Results from a multi-country farm household sample. Prepared for presentation at the American Agricultural Economics Association Annual Meeting, July 27-29, 2008. Orlando, Florida, USA.

Salami, A., Kamara, A.B., Brixiova, Z. 2010. Smallholder Agriculture in East Africa: Trends, Constraints and Opportunities. Working Papers Series. No 105, African Development Bank, Tunis, Tunisia.

Schalkwyk, H., Groenewald, J., Fraser, G., Obi, A. and van Tilbny, A. 2012. Unlocking Markets for Smallholder Farmers in South Africa. Wageningen Academic Publishers. Wageningen.

Seville, D., Buxton, A. and Vorley, B. 2011. Under what conditions are value-chains effective tools for pro-poor development? International Institute for Environment and Development / Sustainable Food Lab. IIED. London, United Kingdom.

Southern Africa Food Lab. (SAFL). 2016. Smallholder Farmer Market Segmentation Toolkit: How and why the Toolkit was developed, and lessons learnt from its application in the Mopani and Umkhanyakude districts in South Africa. University of Stellenbosch, Faculty of AgriSciences: SAFL's Supporting Smallholder Agriculture Programme.

World Bank. 2008. World Development Report 2008: Agriculture for Development. Washington DC. USA. 